\title{
Sixty-Four Hour Changes in Oral-Intestinal, Extracellular, and Intracellular Redox Status After an All-Day Maillard-Coated Food Binge Followed by Two Days of Re- dox/Digestion-Balanced Culinary Medicine: A Pilot Single Case Analysis
}

\author{
James A Cocores, MD ${ }^{1,2}$ \\ ${ }^{1}$ Lab-4 Maillard Misuse Solutions, Redox/Digestion-Balanced \\ International Culinary Medicine, and Dynamic Longevity \\ Lifestyles, Palm Springs, FL USA \\ ${ }^{2}$ Adjunct Clinical Assistant Professor, Translational Addiction \\ Neuroscience and Overweight, Department of Psychiatry, \\ University of Florida and McKnight Brain Institute, \\ Gainesville, FL USA 05/28/2008 to 09/2010.
}

\author{
*Corresponding author \\ Dr. JA Cocores, Maillard Misuse Solutions, Lab \#215, 4611 S Congress Avenue, \\ Palm Springs, FL 33461-4742 USA.
}

Submitted:18 Nov 2021; Accepted: 25 Nov 2021; Published: 02 Dec 2021

Citation: JA Cocores. (2021). Sixty-Four Hour Changes in Oral-Intestinal, Extracellular, and Intracellular Redox Status After an All-Day Maillard-Coated Food Binge Followed by Two Days of Redox/Digestion-Balanced Culinary Medicine: A Pilot Single Case Analysis. Adv Nutr Food Sci, 6(2), 62-64.

\begin{abstract}
Browned, melanoidin-coated, and Maillard reaction end-product-covered convenience and fast-foods are as addictive as street drugs. And drive overeating, systemic oxidative stress (SOS: $p E->p H+$ ), and systemic reductive stress (SRS: $p E-<$ $\mathrm{pH}+$ ), overweight, and the leading causes of mortality and morbidity worldwide.

Redox/digestion-balanced culinary medicine protocols are absent as healthcare professionals and the people they serve begin to recognize that Maillard abuse disorder is the main obstacle to self-actualization and a long, accomplished, and content energetically ambulatory extended lifespan.

A PubMed search revealed no studies exhibiting sixty-four-hour changes in oral-intestinal, extracellular, and intracellular redox status after an all-day Maillard-coated food spree followed by two days of redox/digestion-balanced culinary medicine. The purpose of this single case study is to analyze changes, if any, in oral-intestinal, extracellular, and intracellular redox status after an all-day Maillard-coated binge followed by two days of redox/digestion-balanced culinary medicine and examine the feasibility of more extensive investigations.

The participant met inclusion criteria, drank Maillard-rich colas for breakfast, a small pizza, a peanut butter shake for lunch, a double bacon cheeseburger, and a dozen chicken wings for dinner and provided blood and urine samples. The volunteer then underwent redox/digestion-balanced culinary medicine detoxification and provided laboratory samples. TSH, TG/HDL ratio, VLDL/HDL ratio, LDL/HDL ratio, and urine $\mathrm{pH}+$ measured oral-intestinal and extracellular redox status. The neutrophil-to-lymphocyte and platelet-to-lymphocyte ratios assessed intracellular redox status. It took sixty-four hours for the participant's body and mind to neutralize the toxic manifestations of a day-long binge on Maillard reaction intermediate and end-products, melanoidins, advanced glycation end-products (AGEs), and advanced lipoxidation endproducts-coated and containing foods and beverages. More extensive investigations are needed to increase the Maillard abuse detoxification options. Healthcare professionals and the people they serve increasingly recognize that Maillard abuse is the main obstacle to self-actualization and a long, accomplished, and energetically ambulatory lifespan.
\end{abstract}

Keywords: Maillard Abuse Disorder, Maillard Culinary Medicine Detoxification, Redox Biophysics, Systemic Reductive Stress, Systemic Oxidative Stress, Prime Systemic Energy

Introduction

Browned, melanoidin-coated, and Maillard reaction end-product-covered convenience and fast-foods are as addictive as street drugs [1]. And drive overeating, systemic oxidative stress (SOS: $\mathrm{pE}->\mathrm{pH}+$ ), and systemic reductive stress (SRS: $\mathrm{pE}-<\mathrm{pH}+$ ) [2], overweight, and the leading causes of mortality and morbidity 
worldwide [3].

Redox/digestion-balanced culinary medicine protocols are absent as healthcare professionals and the people they serve begin to recognize that Maillard abuse disorder is the main obstacle to self-actualization and a long, accomplished, and content energetically ambulatory extended lifespan. A PubMed search revealed no studies exhibiting sixty-four-hour changes in oral-intestinal, extracellular, and intracellular redox status after an all-day Maillard-coated food spree followed by two days of redox/digestion-balanced culinary medicine.

The purpose of this single case study is to analyze changes, if any, in oral-intestinal, extracellular, and intracellular redox status after an all-day Maillard-coated binge followed by two days of redox/ digestion-balanced culinary medicine and examine the feasibility of more extensive investigations.

\section{Methods}

The participant met inclusion criteria, drank Maillard-rich colas for breakfast, a small pizza, a peanut butter shake for lunch, a double bacon cheeseburger, and a dozen chicken wings for dinner [4]. Forty hours later, he lowered his urine $\mathrm{pH}+$ from its systemic reductive stress (SRS: $\mathrm{pE}-<\mathrm{pH}+$ ) urine $\mathrm{pH}+$ range of 6.7 to 7.7 to the prime systemic energy (PSE: $\mathrm{pE}-\mathrm{pH}+$ ) urine $\mathrm{pH}+$ range of 5.6 to 6.6 by drinking vinegar and testing his urine $\mathrm{pH}+$ at-home using 'Just Fitter $\mathrm{pH}$ Test Strips $\mathrm{pH} 4.5-\mathrm{pH}$ 9.0' before driving to the laboratory to provide blood samples for $\mathrm{CBC}$ with differential and platelet count, comprehensive metabolic panel, lipid panel, and TSH, and a urine sample for routine urinalysis. The par- ticipant returned home and consumed Maillard-free medium-rare grain-fed steak, steamed rapini, and seraphim sauce made primarily of never-heated fresh garlic with lesser amounts of fresh ginger and turmeric roots added. And drove to the laboratory 1.75 hours after consuming the steak and rapini to provide blood and urine samples. The participant returned to the laboratory after indulging in medium-rare steak, twice the previous amount of rapini, and the same amount of seraphim sauce and entering the SRS (pE- < $\mathrm{pH}+$ ) urine $\mathrm{pH}+$ range 6.7 to 7.7 . The subject returned to the laboratory the following day to provide fasting blood and urine samples. TSH, TG/HDL ratio, VLDL/HDL/ratio, LDL/HDL ratio, and urine $\mathrm{pH}+$ measured oral-intestinal and extracellular redox status. The neutrophil-to-lymphocyte and platelet-to-lymphocyte ratios assessed intracellular redox status.

Total systemic stress (TSS) scores equal the addition of percent changes in extracellular and intracellular redox values. TSS scores reflect the amount of oral-intestinal, extracellular, and intracellular systemic oxidative stress ( $\mathrm{SOS}: \mathrm{pE}->\mathrm{pH}+$ ) within the $\mathrm{SOS}$ urine $\mathrm{pH}+$ range of 4.5 to 5.5 and prime systemic energy (PSE: $\mathrm{pE}-=$ $\mathrm{pH}+$ ) urine $\mathrm{pH}+$ range of 5.6 to 6.6. TSS score mirrors oral-intestinal, extracellular, and intracellular systemic reductive stress (SRS: $\mathrm{pE}-<\mathrm{pH}+$ ) within the SRS urine $\mathrm{pH}+$ range of 6.7 to 7.7 .

\section{Results}

Sixty-four hours' worth of changes in oral-intestinal, extracellular, and intracellular redox status detailed in Table 1 occurred after an all-day Maillard-overindulgence followed by two days of redox/ digestion-balanced culinary medicine.

Table 1: Sixty-four-hour changes in oral-intestinal, extracellular, and intracellular redox status after an all-day Maillard binge followed by two days of redox/digestion-balanced culinary medicine

\begin{tabular}{|c|c|c|c|c|c|c|c|}
\hline $\begin{array}{l}\text { Maillard-Free } \\
\text { Food Trial } \\
\text { Overall pH+ }\end{array}$ & $\begin{array}{l}\text { TSH } \\
\text { Thyroid Func- } \\
\text { tion } \\
\text { (TF) \% Change }\end{array}$ & \begin{tabular}{|l|} 
TG/HDL \\
Ratio \\
(THR) \\
$\%$ Change
\end{tabular} & $\begin{array}{l}\text { VLDL/HDL } \\
\text { Ratio } \\
\text { (VHR) } \\
\% \text { Change }\end{array}$ & $\begin{array}{l}\text { LDL/HDL } \\
\text { Ratio } \\
\text { (LHR) } \\
\text { \% Change }\end{array}$ & $\begin{array}{l}\text { Urine pH+ } \\
\text { \% Change } \\
\text { Total Systemic } \\
\text { Stress (TSS) } \\
\text { Score ** }\end{array}$ & $\begin{array}{l}\text { Neut/Lymph } \\
\text { Ratio } \\
\text { (NLR) } \\
\text { \% Change }\end{array}$ & $\begin{array}{l}\text { Plate/Lymph } \\
\text { Ratio } \\
\text { (PLR) } \\
\% \text { Change }\end{array}$ \\
\hline $\begin{array}{l}\text { 5PM Results } \\
40 \text { Hours } \\
\text { Earlier After } \\
\text { a Day-Long } \\
\text { Binge } \\
\text { on Mail- } \\
\text { lard-Coated } \\
\text { Fast-Foods* }\end{array}$ & $\begin{array}{l}5.9 \\
\mathrm{TF}-84 \%\end{array}$ & \begin{tabular}{|l|}
$735 / 37$ \\
19.9 \\
$+333 \%$
\end{tabular} & $\begin{array}{l}126 / 37 \\
3.5 \\
+298 \%\end{array}$ & $\begin{array}{l}101 / 37 \\
2.7 \\
-34 \%\end{array}$ & $\begin{array}{l}7.0 \\
+8 \% \\
\text { TSS +556 }\end{array}$ & $\begin{array}{l}64 / 27 \\
2.4 \\
+14\end{array}$ & $\begin{array}{l}321 / 27 \\
11.9 \\
+21 \%\end{array}$ \\
\hline $\begin{array}{l}30 \text { Minutes } \\
\text { after AM } \\
\text { Vinegar } \\
\mathrm{pH}+2.5\end{array}$ & 3.2 & $\begin{array}{l}159 / 46 \\
3.5\end{array}$ & \begin{tabular}{|l|}
$29 / 46$ \\
0.63
\end{tabular} & $\begin{array}{l}160 / 46 \\
3.5\end{array}$ & 6.0 & $\begin{array}{l}63 / 28 \\
2.3\end{array}$ & $\begin{array}{l}284 / 28 \\
10.1\end{array}$ \\
\hline $\begin{array}{l}1.75 \text { Hours } \\
\text { after } \\
\text { Medium-Rare } \\
\text { Steak, Rapini, } \\
\text { Seraphim } \\
\text { Sauce } \\
\text { pH+6.0 }\end{array}$ & $\begin{array}{l}3.2 \\
\text { TF } 0 \%\end{array}$ & $\begin{array}{l}193 / 44 \\
4.4 \\
+20 \%\end{array}$ & $\begin{array}{l}36 / 44 \\
0.82 \\
+23 \%\end{array}$ & $\begin{array}{l}163 / 44 \\
3.7 \\
+5 \%\end{array}$ & $\begin{array}{l}6.5 \\
+8 \% \\
\text { TSS +76 }\end{array}$ & $\begin{array}{l}65 / 25 \\
2.6 \\
+5 \%\end{array}$ & $\begin{array}{l}298 / 25 \\
11.9 \\
+15 \%\end{array}$ \\
\hline
\end{tabular}




\begin{tabular}{|c|c|c|c|c|c|c|c|}
\hline $\begin{array}{l}2.75 \text { Hours } \\
\text { after Me- } \\
\text { dium-Rare } \\
\text { Steak, 2x Ra- } \\
\text { pini, Seraphim } \\
\text { Sauce } \\
\text { pH+ } 6.4\end{array}$ & $\begin{array}{l}2.7 \\
\mathrm{TF}+16 \%\end{array}$ & $\begin{array}{l}219 / 40 \\
5.5 \\
+20 \%\end{array}$ & $\begin{array}{l}40 / 40 \\
1.0 \\
+18 \%\end{array}$ & $\begin{array}{l}153 / 40 \\
3.8 \\
+3 \%\end{array}$ & $\begin{array}{l}7.5 \\
+15 \% \\
\text { TSS +47 }\end{array}$ & $\begin{array}{l}63 / 28 \\
2.3 \\
-12 \%\end{array}$ & $\begin{array}{l}287 / 28 \\
10.3 \\
-13 \%\end{array}$ \\
\hline $\begin{array}{l}\text { Next Morn- } \\
\text { ing Fasting } \\
\text { Results }\end{array}$ & $\begin{array}{l}3.1 \\
\mathrm{TF}-13 \%\end{array}$ & $\begin{array}{l}139 / 45 \\
3.1 \\
-44 \%\end{array}$ & $\begin{array}{l}25 / 45 \\
0.56 \\
-44 \%\end{array}$ & $\begin{array}{l}154 / 45 \\
3.4 \\
-11 \%\end{array}$ & $\begin{array}{l}5.5 \\
-27 \% \\
\text { TSS - } 146\end{array}$ & $\begin{array}{l}62 / 28 \\
2.2 \\
-4 \%\end{array}$ & $\begin{array}{l}281 / 28 \\
10.0 \\
-3 \%\end{array}$ \\
\hline
\end{tabular}

*Detailed results of a day-long Maillard binge were submitted to the International Journal of Diabetes \& Endocrinology on $11 / 17 / 2021$ [4].

** Total Systemic Stress (TSS) score reflects the amount of oral-intestinal, extracellular, and intracellular systemic oxidative stress (SOS: $\mathrm{pE}->\mathrm{pH}+$ ) within the $\mathrm{SOS}$ urine $\mathrm{pH}+$ range of 4.5 to 5.5 and prime systemic energy (PSE: $\mathrm{pE}-\mathrm{p} \mathrm{pH}+$ ) urine $\mathrm{pH}+$ range of 5.6 to 6.6. TSS score mirrors oral-intestinal, extracellular, and intracellular systemic reductive stress (SRS: $\mathrm{pE}->\mathrm{pH}+$ ) within the SRS urine $\mathrm{pH}+$ range of 6.7 to 7.7 .

\section{Discussion}

It took sixty-four hours for the participant's body and mind to neutralize the toxic manifestations of a day-long binge on Maillard reaction intermediate and end-products, melanoidins, advanced glycation end-products (AGEs), and advanced lipoxidation end-products-coated and containing foods and beverages.

The $86 \%$ drop in TSS score $(556-76=480 / 556 \times 100)$ suggested that the Maillard-free steak, rapini, and seraphim sauce-redox/ digestion-balanced culinary medicine detoxification protocol succeeded. In re-equilibrating oral-intestinal, extracellular, and intracellular spaces from a towering +556 systemic reductive stress (SRS: $\mathrm{pE}-<\mathrm{pH}+$ ) at urine $\mathrm{pH}+7$ to a modest +76 TSS score within prime systemic energy (PSE: $\mathrm{pE}-\mathrm{pH}+$ ) at urine $\mathrm{pH}$ 6.5. Intracellular redox imbalance corrected, and extracellular redox imbalance further improved but did not correct as confirmed by a positive TSS, after the steak, double-portion of rapini, and the same portion of seraphim sauce that moved the urine $\mathrm{pH}+$ up to 7.5, well into SRS $(\mathrm{pE}-<\mathrm{pH}+)$ territory. The simple act of sleeping led to the following day's TSS score of minus-146. All extracellular and intracellular were imminently approaching prime systemic energy (PSE: $\mathrm{pE}-=\mathrm{pH}+$ ).

\section{Conclusion}

More extensive investigations are needed to increase the Maillard abuse detoxification options. Healthcare professionals and the people they serve increasingly recognize that Maillard abuse is the main obstacle to self-actualization and a long, accomplished, and energetically ambulatory lifespan.

\section{Conflict of interest statement}

The author has no conflicts to disclose.

\section{Dedication}

This article is dedicated to Eleni Soumela.

\section{Funding Statement}

No funding was received for this study.

\section{References}

1. Cocores, J. A., \& Gold, M. S. (2009). The Salted Food Addiction Hypothesis may explain overeating and the obesity epidemic. Medical hypotheses, 73(6), 892-899.

2. Cocores JA. Could Maillard ALEs/AGEs Comprised Rapeseed Oil be Frying Immune Response and Sauteing-up Symptomatic COVID-19 and Its Variants? A Pilot Single Case Study Analyzes Colorfully Hedonic Vegetable Oil and Its Potential Influence on Redox Biophysics and Immune Response. Open J Case Rep. 2021 Dec 2:152.

3. Zhang, Q., Ames, J. M., Smith, R. D., Baynes, J. W., \& Metz, T. O. (2009). A perspective on the Maillard reaction and the analysis of protein glycation by mass spectrometry: probing the pathogenesis of chronic disease. Journal of proteome research, 8(2), 754-769.

4. Cocores JA. Novel Redox Measures for Maillard Abuse-Induced Redox Imbalance: A Pilot Single Case Paradigm Analyzing Dietary Pro-oxidant Browned Foods and Their Instant-Influence on Oral-Intestinal, Extracellular, and Intracellular Systemic Oxidative and Reductive Stress and Eventual Association With Leading Causes of Morbidity and Mortality Globally. Accepted by the International Journal of Diabetes \& Endocrinology on 11/23/2021 for publication in Dec.

Copyright: (C2021 Dr. JA Cocores. This is an open-access article distributed under the terms of the Creative Commons Attribution License, which permits unrestricted use, distribution, and reproduction in any medium, provided the original author and source are credited. 